International

Medical Society

http://imedicalsociety.org
Vol. 9 No. 365

doi: $10.3823 / 2236$

\section{Employment of People with Disabilities in Romania}

ORIGINAL

\section{Abstract}

Background: Promoting optimal social integration of people with disabilities, as active citizens, represents a major objective of Romanian health, social and political strategies.

Methods: This paper represents a selective review of the statistic official information, published in 2015, by the National Authority for People with Disabilities (NAPD) and Ministry of Labor, Family, Social Assistance and Elderly (MLFSPEP). It represents an integrative approach, regarding the legislative and socio-economic framework, concerning the social protection, integration and employment of disabled people in Romania.

Results: The total number of disabled people was 759,019 (3.41\% of Romanian population). About 415,852 (54.8\%) were aged between 18 and 64 . Rate of employment of disabled persons is still very small (14\%). People with somatic disability represent the most employed category (38.4\%); least employed were the mental (3.1\%) and psychiatric (5.2\%) categories. About 722 authorized protected units (sheltered employment) were recorded in 2015.

Discussion: A terminology clarification and unification approach, at national level (between concepts of disability vs. handicap), has become a necessity. Romanian legal frame regarding labour policy and working with disabilities imposes material obligations for employers (the $4 \%$ quota system) but also offers fiscal facilities for them. Disabled persons (with accentuated and severe disability/handicap) are exempt from income tax and complementary cumulate the non-taxable income and disability benefits.

Conclusion: This is an integrative approach to the Romanian strategy and policy of (re-) employment of people with disabilities. It underlines the main achievements, improvements and limitations in the
Anghelescu Aurelian 1,2, Bușcă Mihai ${ }^{3}$, Constantin Adina 4 , Andone loana', Anghelescu Lucia AnaMaria $^{5}$, Onose Gelu ${ }^{1,2}$

1 Neuromuscular Rehabilitation Clinic, Teaching Emergency Hospital "Bagdasar-Arseni", Bucharest, Romania.

2 University of Medicine and Pharmacy "Carol Davila", Bucharest.

3 SC Fiatest SRL, Bucharest.

4 Social Assistance for the Elderly, General Direction for Social Assistance and Child Protection, district 3, Bucharest.

5 Department of Anthropology, Sociology and Social Work, Bucharest University, Romania.

\section{Contact information:}

\section{Anghelescu Aurelian.}

Address: Teaching Emergency Hospital "Bagdasar-Arseni", Bucharest, Romania. orcid.org/0000-0002-8055-0541.

Tel: +40720807607 .

झ" aurelian_anghelescu@yahoo.co.uk 
continuous endeavor of implementation of the legislative framework on the protection, integration and inclusion of disabled persons in Romania.

\section{Keywords}

Disability; Handicap (Type,

Degree); Inclusion; Social

Assistance; Law (no. 448).

\section{Introduction}

The World report on disability, published in 2011 by World Health Organization (WHO) and the World Bank, emphasized that more than a billion people in the world (approximately 15\% of the population) experienced disability, and about 200 million of them remained with major difficulties, limitations in functioning and restricted participation [1]. Generally, people with disabilities are predisposed to social inequity, isolation, depression, exclusion, poverty, moral and economic prejudice, lower opportunities to access basic social services, education and economic achievements.

Approaching people with disabilities is an ongoing complex endeavor of a multi-/interdisciplinary team of professionals: medical, sociological, economic and competent political factors (for adequate funding and policies), in conjunction with an informed tandem - the family and the disabled person.

\section{Material and methods}

This paper represents a selective review of the statistic official information, published in 2015, by the National Authority for People with Disabilities (NAPD) and Ministry of Labor, Family, Social Assistance and Elderly (MLFSPEP). It represents an integrative approach, regarding the legislative and socio-economic framework, concerning the social protection, integration and employment of disabled people in Romania.

\section{Results}

In Romania, the total number of disabled people was 759,019 people (in 2015), and 737,885 (in 2014), representing $3.41 \%$ (in 2015) and respectively 3.47\% (in 2014) of the Romanian population $[2,3]$.

The vast majority (741,516 persons, namely $97.7 \%$ ) are in their family's care and/or live independently and only $2.3 \%$ (17,457 people) are institutionalized in residential public institutions of social assistance for disabled adult people [2, 3].

Women represent $53.12 \%$ of the disabled persons. The number of people aged over 50 represents $68.40 \%$ of the total number of the adult disabled persons.

Centralization of data by age group shows that elderly (over 65 years) represent 37.2\% (282,158 people) in the total number of adults with disabilities; about 54.8\% (415,852 persons) are between 18-64 years, range of ages that is considered legally able to work (Figure 1).

Figure 1: Age and gender distribution of disabled people, centralised in 2015 (adapted from $[2,3]$.

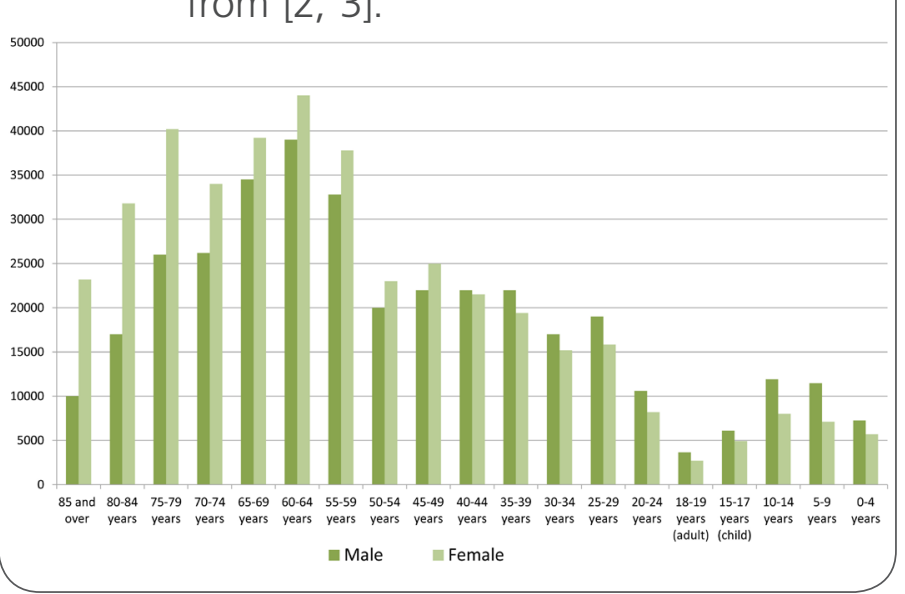


Referring to the legal capacity of the employee, the Labor code (art. 13) stipulates that an individual becomes able to work at the age of 16; employment in heavy, harmful or dangerous jobs (established by Government decision) can be done after the age of 18 [4].

According to the statistical data provided in 2015 by the General department for social assistance and child protection, only 31,691 disabled people were employed, data relatively close to those recorded in 2014 (meaning 30,556) or in $2013(29,842)$ [2, 3] (Figure 2).

Figure 2: The employment rate of persons with and without disabilities, by age groups in 2015 (adapted from [2, 3].

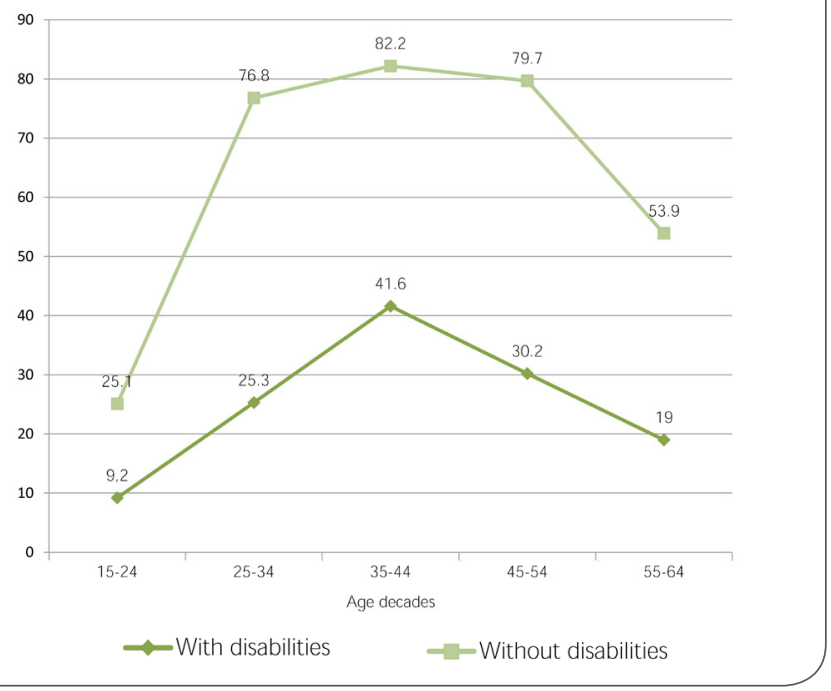

Figure 3: Employed disabled persons, by type of disability/handicap, in 2015 (adapted from $[2,3]$.

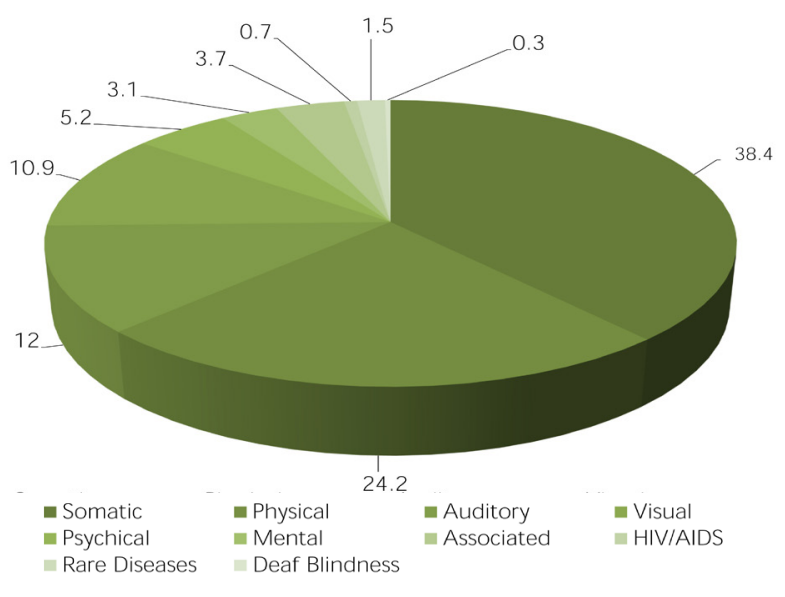

Regarding the type of disability, the most employed category was the somatic one, accounting for $38.4 \%$ of all employed persons with disabilities $[2,3]$. According to $\mathrm{WHO}$, those most excluded from the labor market are mainly those with mental health difficulties or intellectual impairments $[1,2,3]$. The mental (3.1\%) and psychiatric (5.2\%) categories are employed at very tiny percentage [2, 3] (Figure 3).

\section{Discussion}

According to the legislation in force, the people entitled to special social protection are "those people (children and adults, Romanian citizens, citizens of other states or stateless, during their stay or residency in Romania) who live in an inadequate environment for their physical, sensorial, psychic, mental and/or associated disabilities which partially or totally hinder the equal opportunity of access to the community life, and therefore need protection measures for their social integration and inclusion" (art. 2, paragraphs 1 and 2, Law no. 448/2006, modified, revised and republished in 2008, on the protection and the promotion of disabled peoples' rights) [5].

"Disability" characterizes a heterogeneous target group with limited activity and restriction of participation, secondary to a significant loss or deviation of the functions or structures of the organism. It can be congenital or acquired, reversible (or not, with gradual aggravation), with various degrees of severity. Disability can be correlated with disadvantage, but not all disabled people are equally disadvantaged [1] (speaking from medical, as well social points of view, an associated sensorial deficiency with a physical one, such as blindness with complete paraplegia, or overlapping a frustrating poverty, with old age and a severe paralysis, are extremely difficult). Some people acquired disability during their active labor activity; others may have never worked. 
Defining the concepts of "disability" and "handicap" is of tremendous importance in delineating the rights for social protection and respectively the right to work. The beginning of the third millennium brought up a different approach of the disability subject, and of the concept of disabled people (and implicit disabled employee). There has been a paradigm assignation in approach to "disability" and "handicap", a shift from its medical meanings, towards the social significance.

According to the traditional (morpho-physiopathological) understanding, the notion of "handicapped persons" includes people with chronic physical, mental, intellectual or sensorial deficiencies (sequelae), who are permanently or for a long period of time (totally or partially) deprived to act at similar qualitative levels, considered as "normal" for a person with similar age, gender, cultural and social circumstances.

The bio-psycho-social model of Functioning, Disability and Health [6], approaches all health state issues and the pathological categories in an antagonistic tandem: both the "positive" (non-problematic) aspects (functional, physiological levels) and, respectively, the "negative" (problematic) ones (limited/ restricted functionality), on three essential levels of human existence: body, activity, participation.

The label of "handicap", used to indicate the social disadvantage resulting from disturbances/ deficiencies, was changed to the notion of "disability", a generic term used to designate the difficulty of an individual in performing activities, and the problems (restrictions) confronting oneself in situations of life. The actual sense and implications of the content, is shifted from the individual human "entity", to the comunity. "Disability" arises from the interaction between people with a health condition and their environment [1], is seen as a problem of the entire society and not only an individual/ personal one. The whole social system must upgrade its functions and adapt, in order to receive and integrate the people with disabilities, to a level as near as possible to a normal life.

In the most documents of reference, the word "handicap" was replaced gradually by the term of "disability". Professionals involved in the special social protection have manifested a preference to use alternative terminology for the general-concept item "handicapped person" - namely - "disabled person", people with "special requirements" or "special needs". This preference is justified by the less stigmatizing meaning of the latter designations (but still with some discriminatory connotations) according to the international, modern public policies tendencies to broaden the issue of disabilities, in conformity with the principle of "society for all, without discrimination" $[7,8]$.

In Romania is still in use the term "handicap", which refers to the negative repercussions on a person's possibilities to adequately interact in relation to the environment, respectively to participate, with equal chances in the society/ community, and thus to fulfil his/ her strivings, dwelling in accordance with a (quasi-)equivalent to the individuals without problems, quality of life. Practically a "handicap" makes references to the social disadvantages, unequal social or professional integration, compromised economic autonomy/ opportunities.

A terminology clarification and unification approach, at national level, has become a necessity, together with the consequent modification of the related legislation.

At present, the terms of "disability" and "disabled person" are mainly used, except for the name of some laws' titles or the quoting of legal provisions which include the word "handicap" (e.g.: "framing into a handicap degree", "Assessment Commission for handicapped adults", and others). The Assessment Commission is a specialized body of the County Council (or in Bucharest the municipality districts/ sectors), which makes decisions regarding the type and the degree of disability for adult disabled people - attested by the certificate of framing in a 
Figure 4: Schematically representation of the institutional circuit, covered in varying proportions after a disabling event, till the moment of the social inclusion and a possible work reinsertion (adapted from $[5,22]$.

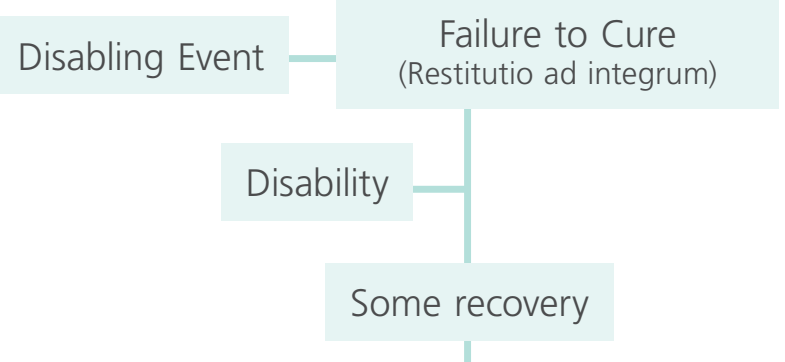

The territorial direction for social assistence within City Halls (a mixed commission, including a doctor): "Comisia de evaluare a persoanelor cu handicap petru adulti", witch determines/frames in handicap degrees and decide related social aides/facilities




handicap degree [5]. The Commission indicates an invalidity pension or individualized vocational training and employment - according to the actual work capacity (Figure 4).

According to the same law no. 448 regarding the protection and promotion of the rights of the disabled people [5], there are 10 types of handicap (physical, visual, hearing, deaf-mute, somatic, mental, psychic, HIV/AIDS, associated, and rare diseases) and 4 levels/ degree of handicap: mild (IV), medium (III), accentuated (II) and severe (I).

In 2015 the number of non-institutionalised disabled adults, was 680,340 [2, 3]. Their distribution by types and degrees of handicap is presented in Figure 5.

Figure 5: The number of non-institutionalised disabled adults, distributed by types and degrees of handicap, in 2015 (adapted from $[2,3]$.

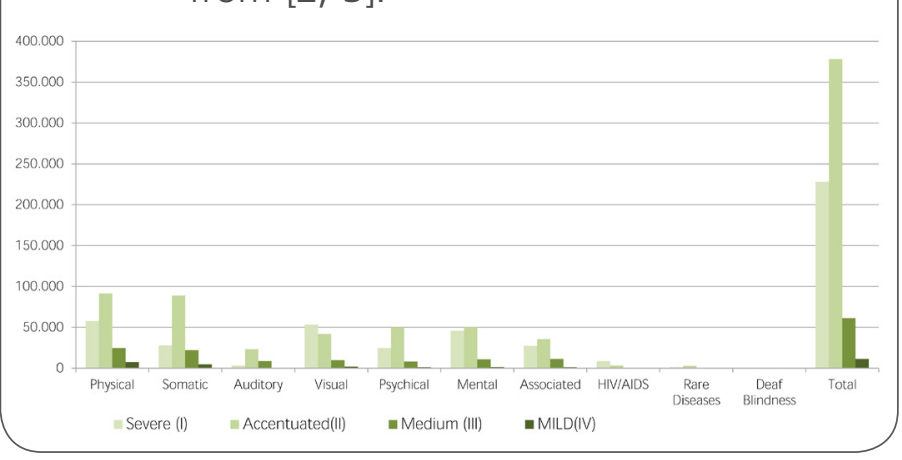

Disabled people classified as severe (I) degree of handicap represents $35.77 \%$ of the total number of them (a slight growing tendency, in comparison with $35.26 \%$ in 2014 , respectively $34.01 \%$ in 2013, reflecting the ascendant prevalence of disability due to population ageing and the global increase in chronic health conditions $[2,3])$. The percentage of people with accentuated degree of handicap was $52.54 \%$ (in 2015), in comparison with $52.97 \%$ in 2014 , and $53.80 \%$ in 2013 . People with medium and mild degree of handicap represented $11.69 \%$ (in 2015), 11.77\% (in 2014) and $12.19 \%$ (in 2013 ) of the total amount of disabled persons $[2,3]$.
Promoting optimal social integration of people with disabilities, as active citizens, able to control their own lives, and with active participation in society, represent a major objective of all health strategies. According to the acting Romanian legislation, the process of social inclusion is the "assembly of multidimensional measures and actions from the fields of social protection, workforce employment, dwelling, education. Health, information-communication, mobility, security, justice and culture, are aiming to control social exclusion and to ensure the active participation of the people to all the economic, social, cultural and political aspects of the society" $[5]$.

The Romanian Government developed the National Strategy for the protection, integration and social inclusion of disabled persons for 2006-2013 aimed at "Equal opportunities for people with handicap - towards a society without discrimination" [7]. For 2014-2020 a National Strategy project for social inclusion of people with disabilities "Social policies - from rehabilitation of the individual to society reform" [8] is pending - possibly in order to be upgraded.

Starting since 2010, Romania developed policies in order to increase accessibility, participation equality, education and professional training, social protection, health and the employment rate of persons with disabilities, in order to build a "barrier-free Europe for all" [9]. According to the Romanian Constitution [10] the right to work cannot be restricted, and "the disabled people enjoy special protection" (stipulated by art.50).

The state authority responsible for the vocational counselling, guidance, integration and employment is represented by the National Agency for Employment and the National Authority for People with Disabilities (NAPD).

Until 2002, the employment rate of the disabled people was never analyzed. Moreover, employment of the disabled people was never, in the past, objective for an active and coherent policy aimed to approach the special social needs of such persons. 
The Romanian electronic registry on disability, founded in 2011 and administrated by MLFSPEP, targets an accurate estimation of the vocational integration degree in this domain. Data concerning inclusive education are collected easier, mainly from the integrator schools. There are some missing elements which prevent an accurate estimation of the degree of vocational integration of the disabled people in Romania. The monitoring of the employment does not last enough to eliminate all risks of dropout, from the part of disabled people.

The percentage of employment of the disabled persons in Romania is still at a relatively small rate: $12.26 \%$ (in 2011) [11] up to $14 \%$ (in 2015) [12], comparatively to the inclusion in the labor market in developed European countries [13] (Norway 61.7\%; Switzerland 62.0\%; Austria 41.9\%; Germany 46.1\%; United Kingdom 38.9\%), or North American ones (Canada 56.3\%; USA 38.1\%). A previous study indicated (in 2009) a rate $12 \%$ return to work of people with SCl-sequelae [14].

Legal regulations and administrative policies have a tremendous impact on the lives of people with disability [15]. According to the current policies regarding employment of disabled people, any person who wants to integrate or re-integrate on the labour market has free access to professional assessment and counselling, no matter the age and the type/degree of the handicap [5]. Moreover, they can receive vocational career advice if he/she is trained and has the corresponding age, if he/she is unemployed and without professional experience, or even he/she is employed, but wants a professional reconversion. The vocational training of the disabled persons is organised by programs of initiation, qualification, re-qualification, further qualification, and specialisation. The number of public institutions of social assistance for adults with disabilities was 411 (in 2015, and 394 in 2014), of which 365 residential and 56 non-residential (day centres) [2, 3].

The employment of disabled people is made on the open labour market, at home, or in authori- sed protected units (sheltered employment), that employ persons with (more severe) disabilities, or as intermediate stage on the open market job. These are entities organized as/ represented by natural or legal persons, public or private; they can be also sections, workshops or other structures within economic operators or public institutions, non-governmental organisations, or they can be organised by an individual authorised disabled person, who can run an independent business, as stipulated by the legislation $[2,3,5,16]$. The rate of disabled personnel must be at least $30 \%$ of the staff. The number of authorized protected units in Romania increased from 400 (in 2010) to 722 units recorded in 2015 [2, 3, 11]. According to the data from the National Institute of Statistics and European reports, over 3,000 non-governmental organisations achieve constant economic activities, under various forms (protected workshops, authorised protected units, social enterprises, etc) [11].

The interaction between disabled persons and Companies is stipulated and ruled by legislative frames, well defined by the EU and Romanian law no. 448 [5]. In accordance with provisions of the law, "any person with disabilities, fit and included in the labor market in Romania is entitled to a reasonable accommodation of the workplace". These consist in the transformation of the physical and informational environment of the products or systems, to make them available also for persons with disabilities, facilities adapted to the special needs of a person in wheelchair.

A multidisciplinary team approach with medical supervision [15, 17, 18] juridical assistance and social support to surpass obstacles during work reintegration, represent important aspects to overcome the environmental and psychological barriers at the company level $[19,20]$.

A favourable psycho-socio-economic chronologic trend in the evolution of a disabled person is to successively progress from the initial medical stage 
("patient"), to the passive/ assisted social status ("consumer"), to a proactive, superior position of "producer"[20] (and, in some countries - a "tax payer"). In Romania disabled persons (with accentuated and severe handicap) are exempt from income tax (fiscal code art. 55) [21]; if they return to work, they complementary cumulate non-taxable income and the disability benefits) [5, 21].

Romanian legal frame regarding labour policy and working with disabilities imposes material obligations for both, public and private employers, but also provides grants and fiscal facilities for them $[5,11,21]$. The $4 \%$ quota system (imposed with a special focus on large companies/ institutions) has a weak implementation in Romania [11], because frequently employers avoid hiring people with disabilities, preferring to pay penalties (instead to implement the quota), or to purchase goods or services from the protected units.

As a general observation, legislation is known by people who are in direct contact with the labour market (employers, employed disabled people, authority representatives, journalists), but there are shortcomings in the practical modality of transmitting information directly to the disabled people, who has not the knowledge and/or the possibility to use internet.

In this respect, the promotion of effective and extensive related general awareness campaigns, through accessible (including for the disabled people) media channels and written materials, the development of knowledge in the area of disability and of research, questing for new assistive technology and means, represents a national priority.

"Working without obstacles: analyzing the policies of EU and Turkey concerning rights of employees with disabilities" [22], and "Successful integration of people living with spinal cord" [23], are two recent European projects which have actively implied Romanian Spinal Cord Society (RoSCoS) as partner, in its continuous endeavors for education and prevention activities, research, therapy, rehabi- litation and vocational reintegration of persons with severe disabilities.

\section{Conclusion}

This rapport reflects the main legislative setting of the Romanian National strategy and policy of social reinsertion; it underlies the improvements as well the limitations of the interaction between the individual and the socio-economical system. A terminology clarification and unification approach, at national level, has become a necessity, together with the consequent modification of the related legislation.

The "disabled people have the right to work, and to get an income" according to the provisions of Romanian labour legislation $[2,3,4,5,10]$, as well as to the special provisions of the law regarding the protection and promotion of the disabled people's rights [5]. Romanian's legal framework on the social protection, integration and inclusion of people with disabilities, is "tuned" to the general EU social policies.

\section{References}

1. WHO, 2011. World report on disability. [online] Available at: www.who.int/disabilities/world report/2011/en. Accessed in Dec. 2015

2. Ministry of Labour, Family, Social Assistance and Elderly, 2014. [online] Available at: http://www.mmuncii.ro/j33/index.php/ ro/2014-domenii/munca/programe-si-strategii. Accessed in Dec. 2015

3. Ministry of Labour, Family, Social Assistance and Elderly [online] Available at: http://www.mmssf.ro/j33/images/buletin statistic/ dizabilitati III2015.pdf. Accessed in Dec. 2015.

4. Labor code, 2006. [online] Available at: http://www.codulmuncii. ro/titlul 2/capitolul 1/art 13 1.html. Accessed in Dec. 2015

5. Law no. 448, Published in Official Gazette (2006), republication OG no.1 (2008), [online] Available at: http://www. equalrightstrust.org/ertdocumentbank/LEGE\%20448\%20 engleza.pdf. Accessed in Dec. 2015

6. WHO, 2011. International Classification of the Functioning, Disability and Health. [online] Available at: http://www.who.int/ classifications/icf/en. Accessed in Dec. 2015 
7. The National Strategy for the protection, integration and social inclusion of the handicapped persons for 2006-2013 "Equal opportunities for people with handicap - towards a society without discrimination" 2005. [online] Available at: http:// www.mmuncii.ro/pub/imagemanager/images/file/Legislatie/ HOTARARI-DE-GUVERN/HG1175-2005.pdf. Accessed in Dec. 2015

8. The National Strategy concerning social inclusion of people with disabilities 2014-2020. "Social policies - from rehabilitation of the individual to society reform", 2014 [online] Available at: http://www.mmuncii.ro/j33/images/Documente/protectie sociala/DPPD/2014-01-31 Strategie DPPD-2014-2020.pdf. Accessed in Dec. 2015

9. European strategy for persons with disabilities 2010-2020 "A renewed commitment to a barrier-free Europe" 2010. [online] Available at: http://eur-lex.europa.eu/LexUriServ/LexUriServ.do? uri=COM:2010:0636:FIN:RO:PDF. Accessed in Dec. 2015

10. Constitution of Romania [online] Available at: http://www.cdep. ro/pls/dic/site.page?id=371. Accessed in Dec. 2015

11. National Institute of Statistics, Press Release no. 258/5.12.2011: "Employment of the disabled. psychology of employers on their commitment" (Ocuparea persoanelor cu dizabilități. psihologia angajatorilor cu privire la angajarea acestora), [online] Available: http://www.dizabilitate.ro/images/elemente/ocuparea persoanelor cu dizabilitati. psihologia angajatorilor cu privire la angajarea persoanelor cu dizabilit.pdf. Accessed in Dec. 2015

12. Mihaela Ungureanu, Romania's policies in support of the rights of persons with disabilities, 2015, UN Headquarters, [online] Available at: http://mpnewyork.mae.ro/en/node/1754. Accessed in Dec. 2015

13. European Commission (2007). Situation of disabled people in the European Union: the European Action Plan 2008-2009. SEC (2007)1548. [online] Available at: http://ec.europa.eu/ transparency/regdoc/rep/2/2007/EN/2-2007-1548-EN-1-0.Pdf. Accessed in Dec. 2015

14. Anghelescu A., Onose G., et al. (2009), ICFDH conceptual approach of the complex medical and social problems (integration at home and inside community), confronting persons with $\mathrm{SCl}$ sequelae, (published in) Proceedings at the National Conference of Neurosurgery and Neurorehabilitation, with international participation, 2nd edition", Romania; (Suppl) Industria Textila Magazine" (Publishing House Certex) pp 54-56

15. Trezzini B, Phillips B., (2014) Impact of legal regulations and administrative policies on persons with $\mathrm{SCl}$ : identifying potential research priorities through expert interviews. Disabil Rehabil;36(22):1883-91

16. Motivation, 2010. Reduced access in the labour market for people with disabilities [online] Available at: http://www. motivation.ro/uploads/studii\%20SAR/Accesul\%20la\%20 piata $\% 20$ muncii $\% 20$ redus $\% 20$ pentru $\% 20$ persoanele $\% 20$ cu\%20dizabilitati.pdf. Accessed in Dec. 2015
17. Onose G., Anghelescu A. Rehabiliation after spinal cord injury SCI [in Romanian], Textbook of Neurosurgery (2011), Publishing House Editura Medicala, Bucharest (ISBN 978 - 973-39-0720-6),

18. Roels EH, Aertgeerts B, Ramaekers D, Peers K. (2016), Hospital and community-based interventions enhancing (re)employment for people with spinal cord injury: a systematic review. Spinal Cord. Spinal Cord. 2016 Jan;54(1):2-7.

19. Employment of people with disabilities. Psychology of employers about hiring people with disabilities, 2014. Available at: http:// www.dizabilitate.ro/images/elementel. Accessed in Dec. 2015

20. Anghelescu A, (2016) Integration and (Re-) Employment of People Living with Sequelae Post Spinal Cord Injury - successful Socioeconomic Evolution - from Cinderella, to the Wonder Princess, Editorial, Int J Neurorehabilitation 3 (2), 1000 e121 http://dx.doi.org/10.4172

21. Fiscal Code, [online] Available at: http://www.pwc.ro/en/ services/tax-legal/alerts.html. Accessed in Dec. 2015]

22. Report: Current situation of policies on the employment/ working conditions for persons with disabilities in Romania (2014), "Working Without Obstacles" [online] Available at: www.icanworkproject.com. Accessed in Dec. 2015]

23. ESCIF Successful integration of people living with spinal cord, 2015 [online] Available at: http://www.escif.org/files/ documents/news/escifintegrationproject. Accessed in Dec. 2015
Publish in International Archives of Medicine

International Archives of Medicine is an open access journal publishing articles encompassing all aspects of medical science and clinical practice. IAM is considered a megajournal with independent sections on all areas of medicine. IAM is a really international journal with authors and board members from all around the world. The journal is widely indexed and classified Q2 in category Medicine. 